\title{
PENYELESAIAN SENGKETA PENGADAAN TANAH GUNA PEMBANGUNAN BANDAR UDARA INTERNASIONAL BERBASIS NILAI KEADILAN SOSIAL
}

\author{
Mia Permata Sari, Suteki \\ Program Studi Magister Kenotariatan, \\ Fakultas Hukum, Universitas Diponegoro
}

\begin{abstract}
$n$ resolving land acquisition disputes for the public interest, it is fitting for the state to pay attention to values outside of the rule of law itself, including the value of social justice and the value of benefits to guarantee the basic rights of affected communities. This study aims to find out what factors cause the settlement of land acquisition disputes in terms of juridical aspects not reflecting the value of justice and benefit for the parties and formulating land acquisition dispute resolution models in a legal socio perspective that can realize the value of social justice and benefits for party. an appropriate method is needed that can accommodate the value of social justice and the benefits in resolving the dispute, among others, promoting the Consensus Meeting and the Need for Alternative Dispute Resolution (ADR) as an alternative solution. In addition, the need to calculate non-physical losses in the assessment of compensation for people who have lost their livelihoods due to land acquisition projects
\end{abstract}

Keywords: Land Acquisition, Land Dispute Settlement, Public Interest

\begin{abstract}
Abstrak
Dalam penyelesaian sengketa pengadaan tanah untuk kepentingan umum sudah sepatutnya negara memperhatikan nilai-nilai diluar daripada aturan hukum itu sendiri, diantaranya nilai keadilan sosial dan nilai kemanfaatan untuk menjamin hak-hak dasar masyarakat terdampak. Penelitian ini bertujuan untuk untuk mengetahui faktor apa saja yang menyebabkan penyelesaian sengketa pengadaan tanah tersebut ditinjau dari aspek yuridis belum mencerminkan nilai keadilan dan kemanfaatan bagi para pihak sertaa merumuskan model penyelesaian sengketa pengadaan tanah dalam perspektif socio legal yang dapat mewujudkan nilai keadilan sosial dan kemanfaatan bagi para pihak. dibutuhkan suatu metode yang tepat yang dapat mengakomodasi nilai keadilan sosial dan kemanfaatan dalam penyelesaian sengketa tersebut diantaranya mengedepankan Musyawarah Mufakat dan Perlunya Alternative Dispute Resolution (ADR) sebagai solusi alternatif.. Selain itu, perlunya memperhitungkan kerugian non fisik dalam penilaian ganti rugi sehingga, terdapat solusi bagi masyarakat yang kehilangan mata pencaharianya akibat proyek pengadaan tanah
\end{abstract}

Kata Kunci : Pengadaan Tanah, Penyelesaian Sengketa Tanah, Kepentingan Umum

\section{A. Pendahuluan}

2013Hubungan tanah dengan negara adalah hubungan yang bersifat "Publicrechterlijk", yaitu hubungan dalam arti bahwa negara "menguasai" seluruh tanah dalam wilayah seluruh 
Negara Kesatuan Republik Indonesia. Adapun pengertian Negara disini adalah sebagai organisasi yang merupakan kekuasaan tertinggi dari seluruh Rakyat Indonesia seperti tertuang dalam pasal 2 Undang-undang No.5 tahun 1960 tentang Peraturan Dasar PokokPokok Agraria (Lembaran Negara Republik Indonesia Tahun 1960 Nomor 104, Tambahan Lembaran Negara Republik Indonesia Nomor 2043) (selanjutnya disingkat UUPA).(Mohammad Hatta, 2006) Berkaitan dengan pasal tersebut, Pasal 33 Undangundang Dasar 1945 memberikan wewenang kepada negara bahwa : "Bumi, air dan ruang angkasa serta kekayaan alam yang terkandung di dalamnya dikuasai oleh negara dan dipergunakan untuk sebesar-besar kemakmuran rakyat”.

Hak menguasai negara atas tanah dan yang terkandung didalamnya tersebut diatas termasuk juga pengadaan tanah yang akan digunakan untuk kepentingan umum. Pengadaan tanah untuk kepentingan umum bertujuan untuk menyediakan tanah bagi pelaksanaan pembangunan guna meningkatkan kesejahteraan dan kemakmuran bangsa, negara dan masyarakat dengan tetap menjamin kepentingan hukum pihak yang berhak.(Badriyah Harun, 2013) Pengadaan tanah bertujuan untuk pembangunan fasilitas kepentingan umum, sehingga harus ada kriteria yang pasti tetang arti atau kategori dari kepentingan umum itu sendiri.

Setidaknya sampai saat ini masih terdapat warga-warga yang tergabung dalam Paguyuban Warga Penolak Penggusuran Kulonprogo (PWPP-KP) kokoh dalam pendiriannya menolak mega proyek tersebut. Adapun sebelumnya terdapat paguyuban yang menolak didirikannya Bandara yang tergabung dalam Paguyuban Wahana Tri Tunggal (WTT).

Tidak hanya permasalahan mengenai penolakan warga, permasalahan prosedural juga terjadi dalam pembangunan Bandar Udara Internasional Yogyakarta. Pembangunan yang rencananya menghabiskan dana Trilyunan rupiah tersebut tidak diawali dengan prosedur yang tepat. Salah satunya adalah mengenai studi analisis dampak lingkungan (Amdal) yang tidak kunjung selesai sehingga mengalami keterlambatan. ${ }^{1}$

Dalam sebagian besar tanah yang dibebaskan ,besaran ganti rugi yang diberikan oleh pemerintah yang diklaim oleh pemerintah sudah lebih besar dari Nilai Jual Obyek Pajak tanah tersebut. Selain itu, pemerintah Kabupaten Kulonprogo juga telah menyiapkan tanah pengganti sebagai upaya relokasi warga, namun banyak warga memilih untuk tidak menempatinya.

\footnotetext{
${ }^{1}$ http://jateng.metrotvnews.com/peristiwa/nN9JGJeb-studi-amdal-telat-pembangunan-bandara-kulon-progo-cacathukum diakses tanggal 11 Januari 2018 pukul 10.15 wib
} 
Begitupula dengan nasib para warga yang terkena dampak ini dari kalangan petani petambak, peternak, rumah makan dan penginapan yang semula menggarap tanah Pakualaman Ground. Puro Pakualaman setidaknya telah menerima ganti kerugian atas tanah Pakualaman Ground yang menjadi dampak pembangunan bandara senilai Rp.727 milyar rupiah (tujuh ratus duapuluh tujuh milyar rupiah), namun kompensasi terhadap warga penggarap yang bermatapencaharian diatas tanah Pakualaman Ground belum terakomodasi dengan baik, terutama perihal reorientasi usaha setelah adanya pembangunan. ${ }^{2}$

Dengan masih adanya warga-warga yang tetap menduduki tanahnya dan menolak dengan adanya pembangunan bandara tersebut serta adanya upaya paksa aparat keamanan yang terindikasi menggunakan cara-cara kekerasan dalam melakukan penggusuran terhadap warga, memberikan indikasi bahwa penyelesaian sengketa yang dilakukan oleh pemerintah belum sepenuhnya mencerminkan nilai keadilan sosial dan kemanfaatan bagi masyarakat yang terdampak langsung oleh adanya pembangunan bandara Internasional Yogyakarta. ${ }^{3}$

Melihat kompleksitas permasalahan yang terjadi dalam upaya pembebasan tanah guna pembangunan bandar udara Internasional Yogyakarta di Kabupaten Kulonprogo ini, banyak pihak menilai bahwa proses penyelesaian sengketa ini masih belum seluruhnya mencerminkan nilai keadilan sosial dan kemanfaatan bagi para pihak. Maka, penulis menganggap bahwa penting untuk melihat dan menguraikan bagaimana penyelesaian sengketa dalam pembangunan ini masih belum seluruhnya mencerminkan nilai keadilan sosial dan kemanfaatan. Selain itu, juga penting merumuskan atau mencari sebuah metode yang tepat didalamnya yang mengedepankan nilai-nilai keadilan sosial dan kemanfaatan khususnya bagi masyarakat terdampak.

Sehingga, "Penyelesaian Sengketa Pembebasan Tanah guna Pembangunan Bandar Udara Internasional berbasis Nilai Keadilan Sosial dan Kemanfaatan (Studi Kasus Bandara Internasional Yogyakarta)" menjadi judul dalam penulisan tesis ini.

Berdasarkan latar belakang tersebut, dirumuskan beberapa masalah, antara lain :

1) Apakah penyelesaian sengketa pengadaan tanah Bandar Udara Internasional Yogyakarta belum mencerminkan nilai keadilan sosial dan kemanfaatan bagi para pihak?

2) Bagaimana model penyelesaian sengketa pengadaan lahan dalam perspektif socio legal yang dapat mewujudkan nilai keadilan sosial dan kemanfaatan bagi para pihak?

\footnotetext{
${ }^{2}$ http://regional.liputan6.com/read/2602655/bagaimana-nasib-penggarap-lahan-bandara-kulon-progo diakses pada tanggal 12 Januari 2018 pukul 10.00 wib

3 https://news.detik.com/berita-jawa-tengah/d-3772046/komnas-ham-datangi-rumah-warga-penolak-bandara-kulonprogo diakses pada tanggal 13 Januari 2018
} 


\section{B. Metode Penelitian}

Berdasarkan perumusan masalah dan tujuan penelitian, maka pendekatan yang digunakan dalam penelitian ini adalah socio-legal research ( penelitian socio legal). Didalam pendekatan socio legal research berarti terdapat dua aspek penelitian. Pertama, aspek legal research .yakni objek penelitian tetap ada yang berupa hukum dalam arti "norm" peraturan perundang-undangan dan kedua, socio research yaitu digunakan metode dan teori ilmu-ilmu sosial tentang hukum untuk membantu peneliti dalam melakukan melakukan analisis. (Suteki, 2018) Data yang dipergunakan dalam penelitian ini adalah data primer dan data sekunder. Untuk memperoleh data primer, dilakukan wawancara kepada informan yang terdiri dari pihak/ instansi berkaitan dengan pengadaan tanah dalam hal ini Pemerintah Kabupaten Kulonprogo, serta beberapa perwakilan masyarakat terdampak pengadaan tanah Bandar Udara Internasional Yogyakarta.

Wawancara yang dilakukan adalah wawancara tidak berstruktur, yaitu wawancara yang dilakukan dengan tidak dibatasi oleh waktu dan daftar urutan pertanyaan, tetapi tetap berpegang pada pokok penting permasalahan yang sesuai dengan tujuan wawancara. Wawancara tidak berstruktur ini dimaksudkan agar memperoleh jawaban spontan dan gambaran yang lebih luas tentang masalah yang diteliti. (Soemitro, 2000)Data sekunder sebagai data penunjang yang menjadi bekal melakukan penelitian dilapangan. Data sekunder meliputi peraturan perundang-undangan terkait dengan pengadaan tanah, literatur-literatur pendukung. Bahan kepustakaan yang berisikan tentang karya ilmiah dari kalangan hukum yang berupa hasil-hasil penelitian, serta karya ilmiah tentang pengadaan tanah untuk kepentingan umum. Teknik analisis data yang digunakan dalam penelitian ini adalah metode analisis kualitatif. Metode analisis data ini merupakan hasil dari data yang diperoleh pada waktu penelitian untuk diambil hasilnya serta dapat disimpulkan kebenarannya. Cara untuk mendapatkan hasil penelitian menggunakan metode induktif. Metode induktif merupakan suatu cara penelitian yang berangkat dari fakta-fakta yang ditemukan di lapangan kemudian dianalisis dengan konsep dan teori yang digunakan dalam penelitian.

\section{Hasil dan Pembahasan}

\section{Penyelesaian Sengketa Pengadaan Tanah Bandar Udara Internasional Yogyakarta.}

Dalam hal ini, dapat diidentifikasi terdapat beberapa permasalahan atau sengketa yang dalam penyelesaiannya perlu adanya evaluasi terkait penyelesaian sengketa terhadap : Mekanisme konsinyasi yang berujung pada pemutusan aliran listrik serta pembatasan akses jalan bagi warga yang tidak mau tanahnya diukur, menduduki tanahnya dan tidak 
mau pindah tanpa permintaan apapun. Masyarakat ini tergabung dalam PWPP-KP (Paguyuban Warga Penolak Penggusuran Kulonprogo).

Ratusan eks petani peggarap tanah Pakualaman yang secara turun temurun telah mengusahakan, memanfaatkan tanah tersebut secara turun temurun dan menjadikan tanah tersebut sebagai satu-satunya mata pencaharian utama. Para petani penggarap pakualaman ground tidak mendapatkan kompensasi maupun gantirugi atas kerugian non fisik yang timbul dikarenakan tidak memiliki alas hak yang sah dalam kepemilikan tanah tersebut. Tanah yang dikelola oleh warga petani tersebut dulunya adalah tanah tandus dan tidak produktif. Kemudian dikelola secara terus menerus hingga menjadi lahan produktif yang menghasilkan komoditas unggulan kulonprogo diantaranya cabai, melon dan beberapa tambak. ${ }^{4}$ Saat ini banyak warga petani yang kehilangan mata pencahariannya dikarenakan tidak memiliki skill lain dan tidak memiliki lahan lain selain lahan yang diusahakan tersebut.

\section{Analisis Penyelesaian Sengketa Pengadaan Tanah Bandara Internasional Yogyakarta.}

Bagi masyarakat Indonesia terutama masyarakat jawa, tanah merupakan harkat dan martabat bagi dirinya dan leluhurnya. Sehingga terdapat kalimat “ sedumuk bathuk sanyari bumi" yang artinya bahwa jika sejengkal saja tanahnya "diusik" maka nyawa mereka akan mempertahankan sampai dengan titik darah penghabisan atau sampai habis nyawa yang dimilikinya. Maka, pertentangan mengenai penolakan pembangunan bandara adalah hal yang lumrah terjadi dalam setiap pengadaaan tanah.

"Pemerintah juga Angkasa Pura I telah melakukan berbagai pendekatan kepada masyarakat yang menolak itu sebagai bentuk upaya untuk agar masyarakat mau untuk tanahnya di ukur,dinilai dan diberikan ganti rugi,

Terhadap tanah-tanah warga yang menolak untuk diukur atau dinilai oleh Badan Pertanahan Nasional sebagai tim pelaksana pembangunan, maka ganti rugi berdasarkan penilaian tim appraisal akan dititipkan ke Pengadilan Negeri atau disebut dengan Proses Konsinyasi. Konsinyasi berasal dari kata "Consignatie" yang artinya penitipan yang dilakukan debitur di Kantor Pengadilan Negeri karena kreditur tidak mau menerima pembayaran debitur.(Meilya Normawaty Simanjutak, n.d.) Beberapa

\footnotetext{
${ }^{4}$ Wawancara EksWarga Penggarap Pakualaman Ground pada tanggal 22-2-2018

${ }^{5}$ Wawancara Seksi Inventarisasi Dan Identifikasi Pertanahan Dinas Pertanahan Dan Tata Ruang Pada Tanggal 31 $1-2018$
} 
ketentuan mengenai praktik konsinyasi tertuang dalam Pasal 1404-1412 Kitab Undang-undang Hukum Perdata (KUHPerdata).

Istilah lembaga hukum konsinyasi dipergunakan oleh sejumlah ahli hukum secara eksplisit untuk mendefenisikan mekanisme penitipan uang ganti rugi ke pengadilan dalam kegiatan pengadaan tanah yang merujuk pada ketentuan Pasal 1404-1412 KUH Perdata.(Lieke Lianadevi Tukgali, 2010)

Menurut Pasal 42 UU 2/2012 bahwa penitipan ganti kerugian ke pengadilan negeri terjadi karena disebabkan oleh:

Pihak yang berhak menerima ganti kerugian menolak bentuk dan/atau besarnya ganti kerugian berdasarkan hasil musyawarah ataupun berdasarkan putusan pengadilan atau Mahkamah Agung, Pihak yang berhak menerima ganti kerugian tidak diketahui keberadaannya; atau Objek Pengadaan Tanah yang akan diberikan ganti kerugian: a. sedang menjadi objek perkara di pengadilan; b. masih dipersengketakan kepemilikannya;c.diletakkan sita oleh pejabat yang berwenang; atau d. menjadi jaminan di bank.

Ketentuan diatas secara eksplisit bahwa penitipan uang ganti kerugian ke pengadilan negeri dapat dilaksanakan apabila pihak yang berhak atas tanah tidak sepakat akan bentuk dan/atau besarnya ganti kerugian yang diberikan kepadanya, padahal sebagaimana diketahui bahwa pengadaan tanah hanya dapat dilakukan atas dasar persetujuan dari pemegang hak atas tanah, baik mengenai bentuk maupun besarnya ganti rugi yang diberikan terhadap tanahnya.(Meilya Normawaty Simanjutak, n.d.)

Persetujuan tersebut harus didapatkan melalui musyawarah untuk mencapai kata sepakat, baik mengenai penyerahan tanah yang bersangkutan maupun pada pemberian ganti ruginya. Sebab pada dasarnya pengadaan tanah tersebut mengandung asas kesepakatan. Asas kesepakatan bermakna bahwa seluruh kegiatan pengadaan tanah dilakukan berdasarkan kesepakatan antara para pihak dan ganti rugi telah diserahkan.(Maria S.W.Sumardjono, 2008)

Penitipan ganti kerugian ke pengadilan ini pada dasarnya bertentangan dengan asas umum pengadaan tanah, sebagaimana diungkapkan oleh Prof. Boedi Harsono bahwa dengan adanya konsinyasi ini seakan-akan bagi rakyat yang bersangkutan hanya ada satu pilihan yaitu mengambil uang ganti rugi tersebut ke pengadilan, atau akan kehilangan tanahnya tanpa ganti rugi.(Meilya Normawaty Simanjutak, n.d.) 
Dalam buku Adrian Sutedi Lebih lanjut, Prof.AP Parlindungan mengungkapkan bahwa tidak mungkin konsinyasi bagi orang yang tidak bersedia menerima uang ganti kerugian. Sikap pemerintah yang menganggap dengan menitipkan uang ke pengadilan negeri berarti telah melakukan kewajibannya dan tidak mempedulikan apakah masyarakat akan mengambil ganti kerugian tersebut atau tidak, mencerminkan tindakan yang tidak didasarkan kepada itikad baik ${ }^{6}$

Undang-Undang No 2 Tahun 2012 banyak dinilai telah bertentangan dengan Undang-Undang Pokok Agraria karena mekanisme yang seharusnya adalah melalui pencabutan hak. Pencabutan hak atas tanah tidak dapat dilakukan secara mudah, sementara konsinyasi dapat dilakukan melalui pengadilan negeri setempat. Pemerintah memilih jalan mudah dan singkat dalam peralihan hak atas tanah sehingga sangat rentan dengan abuse of power.(Aristya Windiana Pamuncak, 2016)

Walaupun konsinyasi memiliki kekuatan hukum karena disebutkan dalam Undang-undang sehingga legal untuk dilakukan, namun perlu dikaji lebih lanjut apakah proses konsinyasi yang dilakukan di lapangan telah memenuhi nilai-nilai keadilan juga mengandung nilai kemanfaatan bagi masyarakat, khususnya masyarakat terdampak.

Konsinyasi yang dilakukan dalam proses pengadaan tanah terhadap warga khususnya yang masih menduduki rumahnya saat ini, oleh kuasa hukum warga dinyatakan tidak memenuhi syarat. Syarat yang dimaksud tertuang dalam pasal 42 ayat (1) dan (2) UU No. 2 tahun 2012 jo. Pasal 25 ayat (2) Peraturan Mahkamah Agung No.3 tahun 2016 yaitu ketiadaan dokumen/berita acara penolakan bentuk dan/atau besaran ganti rugi. Dan juga, dalam faktanya, SPPT PBB yang diterbitkan masih atas nama warga yang tergabung dalam PWPP-KP tersebut." "proses konsinyasi masih berjalan, jadi susah ketika ada bebrapa warga yang tidak memperbolehkan tim untuk mengukur, lalu bagaimana kami dapat melakukan penilaian terhadap rumah atau tanah tersebut, namun itu sedang kami upayakan"8

Sampai dengan pemutusan listrik oleh PLN juga penutupan akses-akses jalan warga yang masih menduduki rumah dan tanahnya ternyata proses konsinyasi atau penitipan ganti rugi tersebut belumlah selesai dilaksanakan. Hal yang menjadi penting

\footnotetext{
${ }^{6}$ Ibid, Hlm 11

${ }^{7}$ www. Instgram/stop.nyia pada tanggal 6-5-2018

${ }^{8}$ Agustinus Heru Atmana Wawancara Kepala Seksi Pengadaan Tanah Kantor BPN Kab.Kulonprogo Pada Tanggal $31-1-2018$
} 
untuk diperhatikan bersama adalah ketika proses konsinyasi belum selesai dilaksanakan (uang belum seluruhnya dititipkan di pengadilan) menandakan bahwa kewajiban dari pihak yang membutuhkan tanah belum seluruhnya diselesaikan.

Dalam proses pengadaan tanah, sebagaimana tertuang dalam Pasal 39 ayat (1) Undang-undang No. 2 tahun 2012 disebutkan dengan jelas bahwa pelepasan hak dilakukan dihadapanan Kantor Pertanahan setempat dan dilaksanakan bersamaan pada saat pemberian ganti kerugian.

Pasal 42 Undang-undang No.2 tahun 2012 juga menyebutkan bahwa pemutusan hubungan hukum antara pihak yang berhak dengan objek pengadaan tanah yang ganti kerugiannya sudah dititipkan di pengadilan negeri sebagaimana diatur dalam Pasal 100-108 Peraturan Presiden Nomor 71 tahun 2012. Pemutusan sambungan aliran listrik dan penutupan akses jalan masyarakat yang masih menduduki rumah dan tanahnya terkesan bahwa pihak yang membutuhkan tanah berkejar-kejaran dengan waktu pembangunan dengan kurang memperhatikan hak dari masyarakat terdampak tersebut. Sebagaimana diketahui bahwa sebagian besar pengadaan tanah bandara tersebut menggunakan cara penyelesaian sengketa dengan konsinyasi.

Dengan demikian jika konsinyasi hanya dijadikan sebuah lembaga yang melegalkan pengambilan paksa tanah masyarakat, dikhawatirkan dapat menjadi celah dilakukannya tindakan-tindakan yang bertentangan dengan nilai keadilan dan penegakan hak asasi manusia. Oleh karena itu dibutuhkan adanya keinginan yang kuat untuk melakukan reformasi hukum pertanahan yang bersendikan kepada nilai-nilai keadilan, yang menempatkan hak asasi manusia sebagai salah satu tugas yang diemban bersama untuk dapat mewujudkan keadilan yang dikehendaki oleh semua kalangan tanpa menyebabkan proses pembangunan terhambat.

Keadilan sosial merupakan perilaku untuk memberikan kepada orang lain apa yang menjadi hak nya demi terwujudnya masyarakat yang sejahtera. Kesejahteraan merupakan tujuan utama dari adanya keadilan sosial.(Suteki, 2018) Jika kita sepakat bahwa pembangunan haruslah bermuara pada kesejahteraan bagi seluruh lapisan masyarakat atau disebut pula keadilan sosial, maka dengan belum diselesaikannya konsinyasi yang menjadi kewajiban dari Angkasa Pura I tindakan yang dilakukan dalam memutus aliran listrik dan penutupan akses jalan bagi warga yang menolak pembangunan bandara sebagai bentuk shock therapy atau upaya menyelesaikan sengketa dalam kurun waktu yang relatif lama adalah tidak mencerminkan nilai 
keadilan sosial serta tidak memberikan nilai kemanfaatan bagi masyarakat. Sebab, hal tersebut menghambat aktivitas warga dalam bersosialisai sehri-hari , juga menghambat aktifitas ekonomi warga dalam bekerja.

Secara umum memang pemilik tanah tidak bisa menolak langkah-langkah pengambil alihan tanah yang telah ditetapkan pemerintah. Agar tidak memicu timbulnya sengketa, walaupun hal ini dapat dilakukan pemerintah tidak harus melakukan pengambilalihan tanah secara paksa. Adapun cara lain untuk mendapatkan tanah warga yang menolak ini juga untuk menjamin keadilan sosial dan memberikan nilai kemanfaatan bagi warga adalah dengan cara negoisasi langsung, melakukan kerjasama dengan pemilik tanah atau melakukan kesepakatan melalui perundingan pengambil alihan tanah. ${ }^{9}$

Yang kedua, terkait dengan penyelesaian sengketa dengan ratusan eks penggarap pakualaman ground. Suyitno, Pakar Hukum agraria mengatakan bahwa Tanah di DIY terdiri dari tanah kasultanan dan kadipaten. Sebagian tanah kasultanan dan kadipaten diberikan pada non-pribumi dengan hukum barat. Bagi pribumi pada tahun 1918, kasultanan membentuk kelurahan di pedesaan. Dengan Rijksblad, kelurahan yang dibentuk diberi hak anggadoh. Tanah yang dimanfaatkan diberikan hak pakai turun temurun yang kemudian sebagian sudah diubah menjadi hak milik. ${ }^{10}$

Sejak diberlakukannya UU No.5 tahun 1960 atau apa yang disebut dengan UUPA di daerah Istimewa Yogyakarta berlaku pula ketentuan bahwa semua tanah yang tidak dapat dibuktikan secara hak oleh pihak lain adalah domain Keraton Yogyakarta dan Puro Pakualaman. Keraton memberikan hak Anggadoh turun temurun kepada rakyat yang nyata-nyata dipergunakan rakyat dan mulai muncul Buku Administrasi Tanah di tiap-tiap kelurahan. Tanah ini termasuk dalam golongan tanah keraton yang masih digarap oleh masyarakat, tidak ada bangunan, baik dengan ijin maupun tidak.

Dengan adanya pembangunan tersebut, para petani penggarap PAG tidak mendapatkan ganti rugi terkait dengan lepasnya sumber mata pencaharian mereka. "kemarin ada beberapa yang diganti, tapi tidak seberapa, misalnya kalau masih ada cabai atau tanaman yang ada diatasnya dibeli lah istilahnya, tetapi dengan adanya

\footnotetext{
9 Sudjarwo Marsoem, Wahyono Adi, Dkk, Op.Cit, Hlm 122

${ }^{10}$ Suyitno, Pemaparan sebagai pembicara dalam Focus Group Discussion “Menuju Jogja Keren dan Ngageni” yang diselenggarakan Harian Jogja pada tanggal 22 Februari 2018
} 
konflik tersebut yang sudah lama ini, banyak warga yang sudah menghentikan aktifitasnya dalam bertani, sehingga tidak mendapatkan apapun, yang kami tuntut adalah ganti rugi atas apa yang telah kami lakukan dengan tanah tandus tersebut. Kami sudah mengeluarkan banyak biaya seperti meratakan tanah dengan alat berat, membeli pupuk dan merawat tanah tersebut agar dapat dimanfaatkan, juga saat ini banyak diantara kami yang kehilangan mata pencaharian”

Pengertian ganti rugi menurut Pasal 1 angka 10 Undang-Undang No 2 Tahun 2012 yang menyatakan ganti kerugian adalah penggantian yang layak dan adil kepada pihak yang berhak dalam proses pengadaan tanah. Kata "layak dan adil" tidak ada penjelasan yang spesifik, namun dalam penjelasan Pasal 2 Huruf $\mathrm{b}$ memperjelas asas keadilan yaitu memberikan jaminan penggantian yang layak kepada Pihak yang Berhak dalam proses Pengadaan Tanah sehingga mendapatkan kesempatan untuk dapat melangsungkan kehidupan yang lebih baik.

Penilaian besarnya nilai Ganti Kerugian oleh Penilai sebagaimana dimaksud dalam Pasal 32 ayat (1) Undang-undang Nomor 2 tahun 2012 dilakukan pada bidang per bidang tanah, meliputi:a). tanah; b) ; ruang atas tanah dan bawah tanah; c)bangunan; d) tanaman; e) benda yang berkaitan dengan tanah; dan/atau kerugian lain yang dapat dinilai. Pemberian Ganti Kerugian dapat diberikan dalam bentuk: ${ }^{11}$ uang, tanah pengganti,permukiman kembali,kepemilikan saham, bentuk lain yang disetujui oleh kedua belah pihak Pada Bagian Penjelas undang-undang ini, bahwa Ganti Kerugian diberikan kepada pemegang Hak atas Tanah. Untuk hak guna bangunan atau hak pakai yang berada di atas tanah yang bukan miliknya, Ganti Kerugian diberikan kepada pemegang hak guna bangunan atau hak pakai atas bangunan, tanaman, atau benda lain yang berkaitan dengan tanah yang dimiliki atau dipunyainya, sedangkan Ganti Kerugian atas tanahnya diberikan kepada pemegang hak milik atau hak pengelolaan. Ganti Kerugian atas tanah hak ulayat diberikan dalam bentuk tanah pengganti, permukiman kembali, atau bentuk lain yang disepakati oleh masyarakat hukum adat yang bersangkutan. Pihak yang menguasai tanah negara yang dapat diberikan Ganti Kerugian adalah pemakai tanah negara yang sesuai dengan atau tidak melanggar ketentuan peraturan perundang-undangan. Misalnya, bekas pemegang hak yang telah habis jangka waktunya yang masih menggunakan atau memanfaatkan

\footnotetext{
${ }^{11}$ Pasal 36 Undang-Undang Nomor 2 Tahun 2012
} 
tanah yang bersangkutan, pihak yang menguasai tanah negara berdasarkan sewamenyewa, atau pihak lain yang menggunakan atau memanfaatkan tanah negara bebas dengan tidak melanggar ketentuan peraturan perundang-undangan.

Tim penilai, terhadap tanah warga eks penggarap tanah pakualaman ground memberikan ganti rugi atas tanaman diatas tanah tersbut pada saat penilaian. Namun, hal ini rupanya belum mengakomodasi seluruh kepentingan para petani yang memiliki urgensi lebih tinggi, yakni ganti rugi atas kerugian non fisik sebagaimana penjelasan pasal 33 huruf f UU Nomor 2 tahun $2012,{ }^{12}$ bahwa kerugian lain yang dapat dinilai adalah kerugian nonfisik yang dapat disetarakan dengan nilai uang. Bentuk kerugian tersebut misalnya kehilangan usaha atau pekerjaan, biaya pemindahan tempat, biaya alih profesi dan nilai atas properti sisa. penjelasan tersebut hanya berhenti sampai disitu saja dan aturan turunan dari Undang-undang ini tidak memberikan deskripsi lain tentang kerugian yang bersifat non fisik.

Sudjarwo Marsoem mengatakan bahawa Model peggantian kerugian pengadaan tanah yang bersifat non fisik memiliki dua sisi yang harus dipenuhi. Keduanya adalah penggantian kerugian dimensi non fisik yang bisa dikapitalisasi dan tidak. Kerugian kehilangan usaha atau pekrjaan, biaya pemindahan tempat, biaya alih profesi dan nilai atas properti sisa adalah bentuk penggantian kerugian dimensi non fisik yang bisa dikapitalisasi.

Yang sering menjadi permasalahan, model pengadaan tanah yang hanya berhenti pada pemberian ganti rugi atau kompensasai saja itu sama sekali tidak memerhatikan dan memperhitungkan masalah replacement, resettlement, reconstruction dan rehabilitation terhadap masayarakat yang terdampak proyek pembangunan.

Perhitungan atas kompesasi atu ganti rugi non fisik didasarkan pada dua aspek berikut, yakni aspek aspek sosiologis dan aspek filosofis.

Aspek Sosiologis yaitu Kelemahan Peraturan-peraturan pengadaan tanah yang ada saaat ini adalah konsep atau prinsip regulasi pengadaan tanh yang tidak memperhitungkan kerugian yang bersifat non fisikTidak ada ketentuan yang menunjukkan bahwa pemberian kompensasai itu menjamin kehidupan rakyat yang kehilangan hak atas tanahnya jadi lebih baik. Peraturan yang ada hanya mengatur ganti rugi atau kompensasi atas tanah, bangunan, dan tanaman diatasnya, mengenai kerugian

\footnotetext{
${ }^{12}$ Sudjarwo Marsoem, Op.Cit, Hlm 199
} 
sosiologis dan filosofis tidak diperhatikan Dalam hal ini, apabila dirasa akan membebani keuangan daerah atau keuangan bagi pihak yang memerlukan tanah, dapat dirumuskan dengan sistem sewa kepada petani-petani tersebut dengan harga sewa yang terjangkau. Selain merupakan bentuk ganti rugi non fisik, pemerintah atau pihak yang memerlukan tanah masih dapat mendapatkan pemasukan dari uang sewa yang akan terus berjalan secara terus menerus dari tahun ke tahun.

Petani-petani di Kecamatan temon adalah petani-petani yang produktif yang berpengalaman dalam menciptakan produk-produk pertanian dengan kualitas unggul. Maka, akan sangat disayangkan apabila ratusan sumber daya manusia dibidang pertanian yang sangat potensial tidak diakomodasai dan difasilitasi dengan baik. Hasilhasil peertanian tersebut selain menjadi ladang penghidupan bagi para petani juga dapat meningkatkan Pendapatan Asli Daerah.

Aspek Filosofis yaitu Rawls berpendapat bahwa Memang boleh jadi diminta pengorbanan demi kepentingan umum, tetapi tidak dapat dibenarkan bahwa pengorbanan ini pertama-tama diminta dari orang-orang yang sudah kurang beruntung dalam masyarakat. Menurut Rawls situasi ketidaksamaan harus diberikan aturan yang sedemikian rupa sehingga paling menguntungkan golongan masyarakat yang paling lemah. Oleh karena itu untuk mendapatkan kompensasi/ganti rugi yang ideal (layak) tim penilai ahli yang independen dan kompeten perlu memperhitungkan secara detail dan jelas, baik aspek fisik maupun non fisik dengan standar perhitungan yang baku. Terkait perhitungan aspek non fisik yang menjadi persoalan adalah bagaimana merumuskan alat ukur aspek ganti rugi karena kerugian sosiologis dan filosofis bersifat abstrak. Yang terpenting dari itu adalah harus adanya political will dari pembuat regulasi untuk merumuskan alat ukur atau kriteria kompensasi non fisik sehingga bisa diterjemahkan oleh lembaga eksekutif dalam proses ganti rugi. Dalam hal in yang menjadi acauan adalah nilai-nilai keadilan, kenyamanan, dan kebahagiaan juga penulis tambhakan, harus pula mempertimbangkan nilai kemanfaatan artinya bahwa ganti rugi yang diberikan sebagai bentuk penyelesaian sengketa pengadaan tanah harus memberikan nilai yang lebih baik bagi masyarakat terdampak.

3. Model Penyelesaian Sengketa Pengadaan Tanah Berbasis Nilai Keadilan Sosial Dan Kemanfaatan

Dalam penyelesaian sengketa pengadaan tanah, pemerintah harus memperhatikan beberapa aspek diantaranya aspek yuridis, sosiologis dan filosofis. 
a) Mengedepankan Musyawarah Mufakat dan Perlunya Alternative Dispute Resolution (ADR) . Dalam Proses pengadaan tanah Musyawarah dalam rangka menetapkan bentuk dan/atau besarnya ganti rugi dilakukan antara lembaga pertanahan dengan pihak yang berhak dimana musyawarah dilakukan paling lama 30 hari kerja sejak hasil penilaian dari penilai disampaikan kepada lembaga prtanahan. Menurut perpres Nomor 36 tahun 2005, musyawarah adalah kegiatan yang mengandung proses saling mendengar, saling memberi dan saling menerima pendapat serta keinginan untuk mencapai kesepakatan mengenai bentuk dan besarnya kompensasi dan masalah lain yang berkaitan dengan kegiatan pengadaan tanah atas dasar kesukarelaan dan kesetaraan antaranpihak yang mempunya tanah, bangunan, tanaman dan benda-benda lain yang berkaitan dengan tanah dengan pihak yang memerlukan tanah. Dalam hal pengadaan tanah, posisi pemilik tanah dan pihak yang memerlukan tanah seharusnya dalam posisi setara atau dalam kata lain, muswarah yang dimaksudkan adalah merupakan proses negosisasi atau bergaining (tawar menawar).

b) Menentukan ganti rugi yang sesuai

Prinsip dasar ganti rugi adalah memberikan memberian ganti kerugan yang adil dan layak kepada pihak yang berhak dalam proses pengadaan tanah.Prinsip dasar ganti rugi adalah memberikan penggantian terhadap kerugian yang diderita pemilik lama dalam posisi ekonomi (keuangan )yang sekurang-kurangnya sama dengan sebelum diadakan proyek pembangunan. Dalam penerapan penilaian kompensasi atau ganti rugi nilai fisik, penilai melakukan penilaian berbasis nilai pasar. Disini, penilai memiliki beberapa alternatif pendekatan dalam menghitungnya. Diantaranya pendekatan pasar (market approach), pendekatan pendapatan (income approach), pendekatan biaya (cost approach).Selain daripada melakukan penilaian terhadap kerugian fisik, perlu pula dilakukan penilain keruagian non fisik. Penilai wajib melakukan penilaian terhadap hilangnya sumber finansial secara individual. Misalnya terhadap bidang tanah yang digunakan untuk usaha juga mendapatkan penggantian. Penilai melakukan penghitungan terhadap kerugian berupa akibat kehilangan usaha yang sedang berjalan. Untuk mendapatkan valuasi, penilai menghitung pendapatan rata-rata dari usaha yang berlangsung selama satu tahun terakhir. Nilai kompensasi yang diberikan kepada pemilik usaha sebesar enam bulan pendapatan rata-rata per bulan. 


\section{Simpulan}

1. Sebagai upaya penyelesaian sengketa pengadaan tanah terhadap objek pembangunan Bandara Internasional Yogyakarta, pemerintah juga Angkasa Pura I telah melakukan berbagai upaya yang mengarah kepada penyelesaian yang memenuhi nilai keadilan dan kemanfaatan, diantaranya, memberikan ganti rugi dengan nilai diatas harga pasar dan memberikan rumah relokasi gratis untuk beberapa warga kurang mampu di area tidak jauh dari pemukiman warga sebelumnya. Namun upaya Penyelesaian Sengketa tersebut masih terdapat beberapa catatan dan belum seluruhnya memenuhi nilai keadilan sosial dan kemanfaatan, diantaranya yaitu Terhadap pemutusan sambungan aliran arus listrik dan pembatasan akses jalan masyarakat yang masih menduduki tanahnya karena menolak pembangunan bandara merupakan bentuk penyelesaian sengketa yang tidak mencerminkan nilai keadilan dan nilai kemanfaatan. Landasan atas dilakukannya pemutusan sambungan aliran arus listrik adalah Putusan Pengadilan yang menyatakan bahwa terhadap tanah yang tersebut akan diselesaikan dengan prosedur konsinyasi. Adapun uang ganti rugi yang disebutkan pada saat pemutusan aliran listrik tersebut belumlah dilakukan dibayarkan atau dititipkan seluruhnya ke Pengadilan Negeri Wates. Oleh sebab itu, Sebagaimana tertuang dalam Pasal 39 ayat (1) Undang-undang No. 2 tahun 2012 disebutkan dengan jelas bahwa pelepasan hak dilakukan dihadapanan Kantor Pertanahan setempat dan dilaksanakan bersamaan pada saat pemberian ganti kerugian. Pasal 42 Undang-undang No.2 tahun 2012 juga menyebutkan bahwa pemutusan hubungan hukum antara pihak yang berhak dengan objek pengadaan tanah yang ganti kerugiannya sudah dititipkan di pengadilan negeri sebagaimana diatur dalam Pasal 100-108 Peraturan Presiden Nomor 71 tahun 2012. Artinya bahwa Pemutusan sambungan arus listrik dan penutupan akses jalan terhadap warga yang masih menduduki tanahnya adalah tidak tepat karena menghambat warga dalam beraktivitas termasuk bekerja sehari-sehari sehingga perlu adanya evaluasi menyeluruh terkait pelaksanaan proses konsinyasi tersebut.

Kemudian terhadap eks ratusan petani penggarap pakualaman ground, dalam pelaksanaan pengadaan tanah Bandara Internasional Yogyakarta (NYIA) masih sangat minim diperhatikan yaitu mengenai penggantian ganti rugi atau kompensasi atas kerugian non fisik yang diderita oleh masyarakat terdampak. Hal tersebut dapat dibuktikan dengan sampai dengan saat ini para petani penggarap tanah pakualaman ground tersebut tidak menemukan kejelasan terkait dengan mata pencahariannya yang 
hilang. Tidak pula menerima kompensasi selain kerugian atas tanaman diatas tanah garapannya yang tersisa.Hal tersebut diatas tidak terlepas dari beberapa faktor diantaranya : Proses awal pengadaan tanah yang dinilai kurang melibatkan masyarakat dalam kajian terhadap penentuan lokasi, kurang adanya komunikasi yang dialogis antara pemerintah dengan warga, serta perlunya evaluasi menyeluruh terkait prosedur administratif proses ganti rugi dan konsinyasi

2. Model penyelesaian sengketa pengadaan lahan dalam perspektif socio legal yang dapat mewujudkan nilai keadilan sosial dan kemanfaatan bagi para pihak dan Mengedepankan Musyawarah Mufakat dan Perlunya Alternative Dispute Resolution (ADR) sebagai solusi alternatif dalam penyelesaian sengketa, sebab cara penyelesaian sengketa itu merupakan bagian dari norma sosial yang hidup, atau paling tidak pernah hidup dalam masyarakat. Hal ini dapat kita ketahui dari kenyataan bahwa kehidupan masyarakat lebih berorientasi pada keseimbangan dan keharmonisan dimana semua orang merasa dihormati, dihargai, dan tidak dikalahkan kepentingannya serta Menentukan bentuk dan besaran ganti rugi tidak hanya dengan menilai pada kerugian fisik, namun juga kerugian non fisik dengan pendekatan-pendekatan aspek yuridis, sosiologis dan filosofis. Baik cara perolehan tanah melalui kegiatan pengadaan tanah dengan kata sepakat maupun pencabutan hak (sebagai upaya hukum pamugkas dan final jika pengadaan tanah dengan musyawarah mufakat gagal dilakukan dengan tidak memungkinkan pemindahan lokasi kegiatan ke tempat lain), terhadap subyek hak wajib memberikan imbalan yang layak berupa uang, fasilitas/tanah pengganti sehingga keadaan sosial ekonominya tidak merosot atau menurun.

\section{DAFTAR PUSTAKA}

Aristya Windiana Pamuncak. (2016). Perbandingan Ganti Rugi dan Mekanisme Peralihan Hak Menurut Peraturan Presiden Nomor 65 Tahun 2006 dan Undang - Undang Nomor 2 Tahun 2012. Jurnal Law and Justice, Vol 1 No.1.

Badriyah Harun. (2013). Solusi Sengketa Tanah dan BAngunan. Jakarta: Pustaka Yustisia.

Lieke Lianadevi Tukgali. (2010). Fungsi Sosial Hak Atas Tanah Dalam Pengadaan Tanah Untuk Kepentingan Umum. Jakarta: Kertas Putih Communication.

Maria S.W.Sumardjono. (2008). Tanah Dalam Perspektif Hak Ekonomi Sosial dan Budaya. Jakarta: Kompas.

Meilya Normawaty Simanjutak. (n.d.). Perlindungan Hukum Terhadap Pihak yang Berhak atas Tanah Dalam Hak Ganti rugi.

Mohammad Hatta. (2006). Hukum Tanah NAsional dalam Perspektif. Yogyakarta: Media 
Abadi.

Soemitro, R. H. (2000). Metodologi Penelitian Hukum dan Jurimetri. Bogor: Ghalia Indonesia.

Suteki, G. T. (2018). Metodologi Penelitian Hukum. Raja Grafindo Persada. 